\title{
13 Demonstration and promotion of improved food barley, bread wheat and faba bean technologies
}

\author{
Andualem Tadesse and Wondimu Bayu
}

\section{Introduction}

Agriculture is the mainstay of the Ethiopian national economy, accounting for over 40 per cent of the national gross domestic product, over 90 per cent of national foreign exchange earnings and over 85 per cent of the national labour force. Since 2007 Ethiopia has achieved strong economic growth, making it one of the highest performing economies in sub-Saharan Africa. Yet it remains one of the world's poorest countries. Although a host of factors account for low agricultural productivity, the availability and use of improved agricultural technologies constitute the major limitation to date. In view of this, the government of Ethiopia, in an attempt to increase agricultural productivity and improve food security at both national and household levels, has undertaken efforts to generate and disseminate improved agricultural technologies to smallholder farmers (Mulugeta, 2010).

Over the past two to three decades, on-farm trials and demonstration and popularization of improved crop production technologies have been undertaken in several potential areas to promote improved crop technologies and enhance their adoption. However, adoption of these improved crop varieties was very low. The main reason for the low adoption is that agriculture and rural development in Ethiopia, although claiming to include the participation of farmers, has remained delivery oriented in terms of its extension services rather than encouraging farmers' to innovate (Asfaw et al., 2010). As a result, the adoption rates of many of the technologies generated so far has not been impressive.

Cognizant of this fact, Gondar Agricultural Research Center (GARC) has carried out many participatory research and promotion activities with the general objective of improving the livelihood of the watershed community through introducing improved crop production technologies. The specific objectives of the activities were to:

- demonstrate and evaluate crop technologies in target areas;

- increase farmers' productivity by introducing and adopting improved crop varieties; and 
- enhance farmers' and development agents' technical capacity in crop production and management.

\section{Materials and methods}

During the 2011 and 2012 cropping seasons demonstration and promotion activities were conducted to facilitate the wider adoption of the selected improved bread wheat, food barley and faba bean varieties along with improved production packages (seeding rate, fertilizer rate, sowing time and weeding time) in the Gumara-Maksegnit watershed, Gondar Zuria district of North Gondar zone. 'Estayish' of food barley, 'Tay' of bread wheat and 'Degaga' of faba bean, selected from the 2010 participatory variety selection trials, were demonstrated. 'Estayish' was demonstrated for two years (2011 and 2012) and 'Tay' and 'Degaga' were demonstrated only in 2012. 'Estayish' was planted on twenty farmers' plots in each year where each farmer planted on 0.25 ha of land. 'Tay' was planted on eleven farmers' plots where seven farmers each planted on 0.5 ha and four farmers each planted on 0.25 ha. 'Degaga' was planted on eighteen farmers' plots where sixteen farmers each planted on 0.25 ha and two farmers each planted on 0.5 ha of land. Bread wheat was planted at the seed rate of 150 $\mathrm{kg} / \mathrm{ha}$, food barley at $125 \mathrm{~kg} / \mathrm{ha}$ and faba bean at $100 \mathrm{~kg} / \mathrm{ha}$. Fertilizer was applied at the rates of $100 \mathrm{~kg} / \mathrm{ha}$ of DAP and $100 \mathrm{~kg} / \mathrm{ha}$ of urea for food barley, $100 \mathrm{~kg} / \mathrm{ha}$ of DAP and $125 \mathrm{~kg} / \mathrm{ha}$ of urea for bread wheat, and $100 \mathrm{~kg} / \mathrm{ha}$ of DAP for faba bean. For bread wheat urea application was split in two (at planting and after first weeding) and for food barley it was applied once at planting. All farm operations and agronomic practices were carried out by farmers as per the recommendations with close assistance from development agents and researchers.

Three farmers' research and extension groups (FREGs) with sixty members, representing the upstream and downstream of the watershed, were organized. They participated in the variety selection process and hosted the demonstration and popularization activities. In each year, a one day training session was given on improved production and management of food barley, bread wheat and faba bean crops. In 2011, twenty farmers (four female), three development agents and two district level extension workers were trained. In 2012, eighty farmers (thirteen female) and seven extension staff were trained. A total of 162 production leaflets on each crop type were prepared and distributed on the training and during field days. Farmers' field days were organized to evaluate the demonstration activities where farmers, extension workers, other development workers, multi-disciplinary teams of researchers and district level policy makers attended. About twenty-nine farmers, thirteen extension workers and eight researchers attended in 2011 and in 2012 sixty-five farmers (seven female), seven extension workers (two female), a Gondar Zuria district administrator delegate and four journalists attended the field days. The field visits on the field days were broadcast on Fana FM 98.1 radio and on Ethiopian television. 
Grain yield data was collected using one metre by one metre quadrants from demonstration fields and neighbouring farmers' fields. Simple descriptive statistics and International Maize and Wheat Improvement Center (CIMMYT) partial budget and sensitivity analysis were used to carry out cost-benefit analysis. During the course of this experiment (2012 cropping season), the price of fertilizer used was Ethiopian Birr (ETB) $14.97 / \mathrm{kg}$ for DAP and ETB 12.11/kg for urea. Daily wages were set at ETB 35 per day. The farm gate price of the seed at planting was ETB $6.00 / \mathrm{kg}$ for bread wheat, ETB $5.00 / \mathrm{kg}$ for food barley and ETB $9.00 / \mathrm{kg}$ for faba bean. The farm gate price of the grain at harvest was ETB $6.50 / \mathrm{kg}$ for bread wheat, ETB $7.00 / \mathrm{kg}$ for food barley and ETB $8.00 / \mathrm{kg}$ for faba bean. Estimated labour for hand weeding and harvesting was forty man days/ha for bread wheat, fifteen man days/ha for food barley and ten man days/ha for faba bean. Yield was adjusted downwards by 10 per cent to reflect yields obtained under farmers' conditions.

\section{Results and discussions}

\section{Food barley}

Food barley is the major crop in the high altitude areas in the watershed. However, productivity of the crop is about $1 \mathrm{t} /$ ha which could partly be attributed to the use of low-yielding varieties and unimproved management practices. An improved food barley variety, 'Estayish', was demonstrated. Results obtained by comparing the improved variety under improved management packages with the local variety under farmers' management, showed that grain yield from the improved variety was higher, ranging from $2.2 \mathrm{t} / \mathrm{ha}$ to $2.9 \mathrm{t} / \mathrm{ha}$ as compared to the yield in the neighbouring fields which ranged from $1.6 \mathrm{t} /$ ha to $2.2 \mathrm{t} /$ ha (Table 13.1). The improved variety with the improved package gave a yield advantage of $32-44$ per cent (Table 13.1).

Table 13.1 Grain yield and yield advantage of improved food barley variety Estayish over farmers' local variety

\begin{tabular}{llll}
\hline Farmer & $\begin{array}{l}\text { Yield from } \\
\text { demonstration } \\
\text { plots }(\mathrm{t} / \mathrm{ha})\end{array}$ & $\begin{array}{l}\text { Yield from } \\
\text { neighbouring } \\
\text { field }(\mathrm{t} / \mathrm{ha})\end{array}$ & $\begin{array}{l}\text { Yield } \\
\text { advantage } \\
(\%)\end{array}$ \\
\hline Eyayu Tadesse & 2.2 & 1.6 & 36 \\
Mulu Berihun & 2.9 & 2.2 & 32 \\
Tiget Dessalegn & 2.4 & 1.7 & 41 \\
Dessie Gebru & 2.6 & 1.8 & 44 \\
Mean & 2.53 & 1.83 & \\
\hline
\end{tabular}


Table 13.2 Grain yield and yield advantage of improved bread wheat variety Tay over farmers' variety

\begin{tabular}{llll}
\hline Farmer & $\begin{array}{l}\text { Yield from } \\
\text { demonstration } \\
\text { plots }(\mathrm{t} / \mathrm{ha})\end{array}$ & $\begin{array}{l}\text { Yield from } \\
\text { neighbouring } \\
\text { field }(\mathrm{t} / \mathrm{ha})\end{array}$ & $\begin{array}{l}\text { Yield } \\
\text { advantage } \\
(\%)\end{array}$ \\
\hline Legesse Adugna & 3.24 & 2.20 & 47 \\
Hone Awoke & 3.65 & 2.75 & 33 \\
Lakew Awota & 3.43 & 2.60 & 32 \\
Gizat Awoke & 2.89 & 2.24 & 29 \\
Mean & 3.30 & 2.45 & \\
\hline
\end{tabular}

\section{Bread wheat}

Farmers in the watershed grow a bread wheat variety, 'Kubsa', that is already out of production in other parts of the country due to its susceptibility to stripe rust. Because of this disease, 'Kubsa' is no longer sustainable in the GumaraMaksegnit watershed. Therefore, replacing 'Kubsa' with varieties resistant to stripe rust as well as being high yielding was important. The results of the demonstration and popularization activities on 'Tay' bread wheat variety showed that the improved variety 'Tay' planted with improved management packages gave a yield advantage of 29-47 per cent over the farmers' variety planted under farmers' management practices (Table 13.2).

\section{Faba bean}

Faba bean is one of the most important legume crops in the high altitude areas of the watershed. The crop is an important source of protein, a rotation crop and a cash source. The yield from 'Degaga' ranged from $1.24 \mathrm{t} / \mathrm{ha}$ to $1.71 \mathrm{t} / \mathrm{ha}$ as compared to $0.86 \mathrm{t} / \mathrm{ha}$ to $1.32 \mathrm{t} / \mathrm{ha}$ for the local variety (Table 13.3). Growing 'Degaga' with the improved packages gave a 27-56 per cent yield advantage over growing the local variety with farmers' management practices (Table 13.3).

Table 13.3 Grain yield and yield advantage of the improved faba bean variety Degaga over farmers' local variety

\begin{tabular}{llll}
\hline Farmer & $\begin{array}{l}\text { Yield from } \\
\text { demonstration } \\
\text { plots }(t / h a)\end{array}$ & $\begin{array}{l}\text { Yield from } \\
\text { neighbouring } \\
\text { field }(t / h a)\end{array}$ & $\begin{array}{l}\text { Yield } \\
\text { advantage } \\
(\%)\end{array}$ \\
\hline Melkamu Getu & 1.71 & 1.32 & 30 \\
Mesafint Ambachew & 1.29 & 0.98 & 32 \\
Alew Kebede & 1.24 & 0.98 & 27 \\
Birhanu Ebabu & 1.34 & 0.86 & 56 \\
Mean & 1.34 & 1.04 & \\
\hline
\end{tabular}




\section{Partial budget analysis}

For all the crops, growing improved varieties with improved production packages gave higher net benefits and higher marginal rates of return (MRR) over growing local varieties with local management practices (Table 13.4). Farmers who grew Estayish, Tay and Degaga with their improved production packages earned marginal net benefits of ETB 3,835, ETB 4,397.5 and ETB 1,717 , respectively (Table 13.4).

The MRR for the improved variety of food barley with its production package was 666 per cent, for bread wheat 764 per cent and for faba bean 196 per cent. This implies that, taking bread wheat as an example, for one ETB additional cost incurred on the use of improved varieties with improved production packages, an additional ETB of 7.64 can be obtained after paying the input cost. If farmers spend one ETB for using improved food barley technology they will earn ETB 6.66.

\section{Farmers' evaluation}

During the field days farmers evaluated demonstration plots for each crop (Figure 13.1). Farmers' evaluation compared Estayish with their local variety by setting earliness, number of rows per spike, plant biomass, tillering capacity and waterlogging resistance as criteria and indicated that Estayish out-performed the local variety in all the parameters considered. Similarly, farmers ranked Tay superior to the farmers' variety Kubsa in earliness, biomass yield, spike length, stalk strength, seed size and seed colour. Farmers were impressed with Degaga as it has a prolific pod setting ability, has three to four seeds per pod and has a strong stalk.
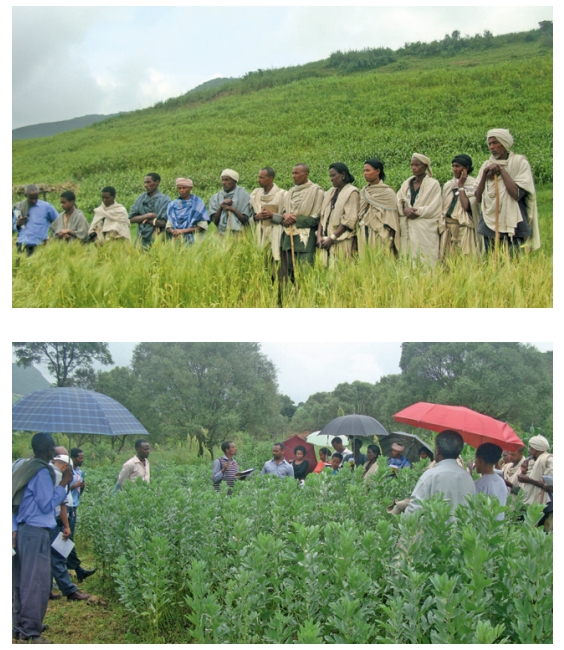

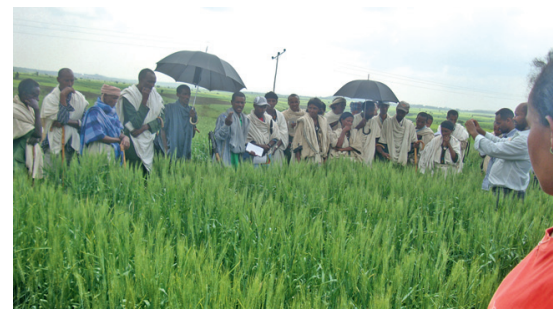

Figure 13.1

Participatory variety selection of food barley (above left), bread wheat (above right) and faba bean (left) 


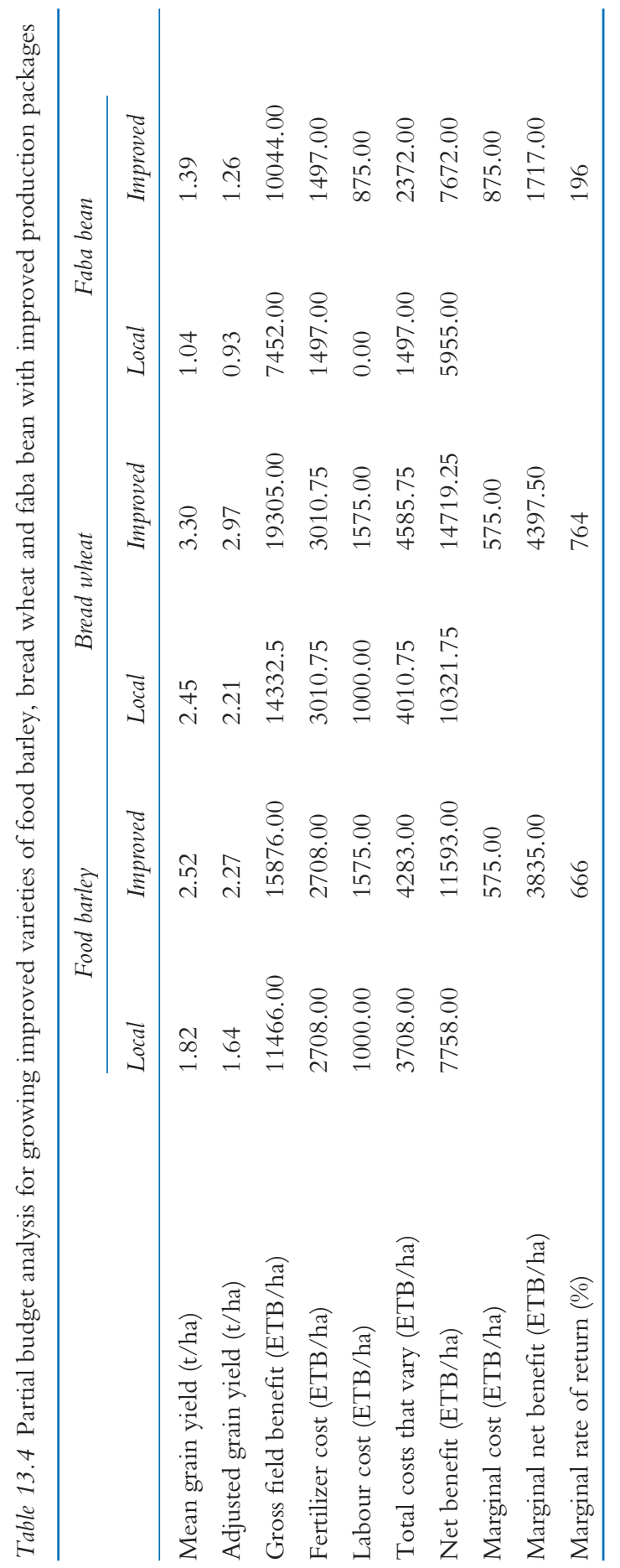




\section{Conclusion}

The objective of this experiment was not to obtain an assessment that is statistically valid but to demonstrate and popularize improved crop varieties with their production packages. It was observed that farmers' participation in variety selection has paramount importance, and it was obvious that farmers demonstrated the ability to select well-adapted and preferred varieties suited to their circumstances using their own criteria. Farmers showed great interest in all the three varieties demonstrated. We recommend that the district office of agriculture gives priority to further scaling up the production of these varieties.

\section{Acknowledgement}

We would like to thank the International Center for Agricultural Research in the Dry Areas (ICARDA) rainfed Ethiopia project for financial support. We would also like to thank our colleagues at GARC for their efforts in support of this research.

\section{References}

Asfaw, S., Shiferaw, B. and Simtowe, F., 2010. 'Does technology adoption promote commercialization? Evidence from chickpea technologies in Ethiopia'. Available online at http://citeseerx.ist.psu.edu/viewdoc/summary?doi=10.1.1.192.6375 (accessed 10 March 2015).

International Maize and Wheat Improvement Center (CIMMYT), 1988. 'From Agronomic Data to Farmer Recommendation: An Economics Training Manual'. CIMMYT, Mexico, MX.

Mulugeta, T. and Hundie, B., 2010. 'Impacts of Adoption of Improved Wheat Technologies on Households' Food Consumption in Southeastern Ethiopia'. Available online at http://ageconsearch.umn.edu/bitstream/126766/2/Mulugeta.pdf (accessed 10 March 2015). 